Research

\title{
Cash transfers, climate shocks vulnerability and households' resilience in Togo
}

\author{
Koffi Sodokin ${ }^{1} \cdot$ Victor Nyatefe $^{1}$
}

Received: 13 November 2020 / Accepted: 21 January 2021

(C) The Author(s) 2021 OPEN

\begin{abstract}
This paper uses data from the survey of basic wellbeing indicators (2015) to investigate climate-related risk perceived impact on the household's living standard in Togo. We investigate the data using a subjective approach with a Probit model and a Propensity Score Matching Method. For the majority of households in the sample, the results suggest, on the one hand, a significant impact of climate-related risk on their living standards. On the other hand, the estimation results show that income from activities increases the resilience and reduction of Togo households' climate-related effects. Finally, remittances increase the households' ability to be less climate vulnerable and play a significant role in the household's resilience building. In terms of public policies, the results imply that a broader consultation and strategy are needed to reduce the consequences of climate related-risks on households in Togo.
\end{abstract}

Keywords Cash transfers · Climate-related risk · Impacts · Vulnerability · Resilience $\cdot$ Probit model $\cdot$ Togo

JEL classification Q540 1380

\section{Introduction}

Generally, the impacts of climate shock on households will be felt most in developing countries already facing development challenges [1-4]. The poorest countries are the most exposed to the impacts of natural disasters (cyclones, tsunamis, floods, drought, land erosion, etc.). They have more vulnerability factors and minimal technical and economic capacities for adaptation (lack insurance, limited weather forecasting systems, etc.) [5-10]. Although policies and agreements are being put in place to address climate change causes, households are also implementing livelihood diversification strategies. These strategies include diversification of income and activities [11-14] to reduce their vulnerability and be more resilient to climate-related shock. Migrant remittances are cited in the literature as one of the critical elements of this strategy [15-22]. Remittances from migrants improve families' wellbeing back home and support their subsistence in times of shocks and climatic stress [23-25].

Migrant remittances are more stable than other forms of private capital flows, particularly in crisis times [26, 27]. Migrant remittances have increased in recent years exceeding Foreign Direct Investment (FDI), Official Development Assistance (ODA), and Portfolio Investment in most countries [28]-[31]. In 2017, all developing countries received US\$466 billion in remittances, an increase of $8.5 \%$ [32] compared to 2016. In Togo, the sums sent each year by the Togolese diaspora are three to four times greater than ODA [33] and reached US\$402 million in 2017 (World Bank 2018), or 8.7\%

Koffi Sodokin, ksodokin@gmail.com; ksodokin@univ-lome.tg; Victor Nyatefe, vnyatefe@gmail.com | 'Lecturer and Researcher At the Research and Training Center in Economics Sciences and Management (CERFEG), FaSEG, University of Lomé, Lomé, Togo. 
of its GDP. Migrant remittances have become the primary source of non-debt generating financing for the country and a critical income source for households.

Several studies that have explored the effects of climate-related impact on households, their vulnerability and resilience in many developing countries have shown that migrant remittances are not only necessary to support the most vulnerable households in their daily lives. These studies show that migrant remittances also constitute a response mechanism to disasters [35]. For instance, in the case of the Philippines, [18, 36] assess the benefits of prospective disaster risk management and interventions, including not just engineering projects but also formal and informal risk-sharing mechanisms (e.g., post-disaster support and private remittances), in terms of increased resilience and reduced natural disaster impacts on all Filipinos' lives and livelihoods. However, the relationship between remittances and household vulnerability and resilience to climate impacts remains unclear and remains limited [37]. Indeed, contextualizing the migration concept about climate change, vulnerability, and resilience lack clarity [38]. The divergence of opinion on the impacts of migration concerning household response strategies to climate change results from a lack of empirical evidence on the relationship between environmental degradation and migration and the methodological challenges this implies [39]. Thus, little empirical work has addressed the linkages between migration impacts (migrant remittances) in different environmental and social contexts [38].

Despite the growing interest in analyzing the role of migrant remittances in strategies to address climate change impacts, vulnerability, and resilience, little attention has been paid to the topic at the national level. The relationship between climate change and migrant remittances remains unclear, particularly in Togo. Moreover, the previous studies $[40,41]$ focused on the objective measurement of climate's various aspects. More recently, studies based on the subjective approach have been recommended because of their advantages [42]. The subjective approach has been praised for considering households' cognitive and emotional self-assessments of their capabilities and capacities to respond to risk [42]. The literature shows that individuals and communities have always developed learning and adjustment skills, competencies, knowledge, modes of self-organization, and social and institutional links to build resilience to the effects of climate-related risk [34-36, 43,44]. Consequently, several researchers and practitioners show that it is better to understand people's perceptions of the effects of climate-related impacts, their state of vulnerability, and the mechanisms for adaptation and resilience., Therefore the strengthening of these strategies should help reduce their exposure and increase their resilience to climate change.

This paper aims to examine the determinants of subjective perceptions of climate change, vulnerability, and resilience within households in Togo. It seeks to analyze the potential role of migrant remittances in mitigating climate impacts, exposure, and resilience-building of Togolese households using a subjective approach. This work is relevant to Togo for several reasons. First, to the best of our knowledge, this is the first study that attempts to understand remittances' potential as a coping and resilience-building mechanism to households in Togo's face of climate change. Second, although United Nations Development Program (UNDP) carried out a study in 2011 for Togo that took into account all three aspects of climate change, it was less analytical and failed to understand the determinants of subjective perception of climate change, resilience, and vulnerability. Thereby, it is not sufficient to serve as a backbone to enact adequate policies by decision-makers.

Consequently, this does not allow decision-makers to identify the different tools to be adopted to act on such an aspect of climate change. We used a simple probit model to estimate the influence of households' socio-demographic and socio-economic factors on households' socio-demographic and socio-economic characteristics on their subjective perceptions of climate-related risks, vulnerability, and resilience. Using the propensity score matching (PSM) method and ant instrumental variable probit model, we estimated the impact of migrant remittances on household perceptions of climatic events, vulnerability, and resilience. Therefore it is possible to consider the selection and endogeneity biases often inherent in migrant remittances. Our data are from the Survey on Basic Well-being Indicators [89].

There are two contributions to our work to the literature. First is using a subjective approach to analyze the different aspects of vulnerability and resilience to Togo's climate-related impact. Second, it highlights the role of migrant remittances, especially in the world's poorest regions suffering the full effect of climate extremes. Thus, this paper becomes a complementary study that contributes to the literature on the subjective analysis of the impacts of climate on households in Togo.

We organize the re mainder of the paper as follows: Sect. 2 presents a brief literature review. Section 3 describes the methodological approach, Sect. 4 presents the data analysis, and Sect. 5 presents the results and discussions. 


\section{Literature review}

The importance of migrant remittances in response to climate-related risks and their impacts on populations has been the subject of several studies in the literature. Two trends emerge. The first assumes that not enough effort has been made to understand the role of remittances in times of natural disasters. The first reason is that natural disaster management agencies tend to minimize the potential of migrant remittances $[16,27]$. The second reason is that existing studies have used econometric methods to evaluate the effects of migrant remittances in times of disaster without considering populations' perceptions [36, 45-47]. Therefore, these studies say little about the recipients of migrant remittances, the determinants of these remittances, and how these additional resources help communities recover from climate shocks $[37,48]$. Le De et al. [37] it shows that understanding the link between migrant remittances and household vulnerability and resilience involves these resources' roles in households' daily lives. In other words, it involves understanding the behavior of remittances in times of climate crisis and its impact on household adaptation strategies.

Consequently, households would use the funds received to increase pre-existing vulnerability and adopt irreversible livelihood strategies to invest in assets to increase their capacity to become more resilient in a sustainable manner [36, 49-51]. This first trend follows that understanding coping strategies and the role of migrant remittances is of paramount importance to guide risk reduction and natural disaster prevention programs. It is clear from this perspective that populations are more likely to provide information on their state of vulnerability and appreciate the protective measures they adopt. However, most support programs are imposed on people without considering their perceptions [52-54].

The second trend recommends adopting a subjective approach that considers the perceptions, priorities, and values of populations and the severe constraints to which they are exposed [47, 55-58]. These analysis suggest that this form of research would allow grassroots populations to delineate the outcomes of the criteria they perceive to be necessary. Therefore the subjective approach considers the participation of grassroots populations in making decisions about their future $[58,59]$.

Besides, labor migration literature considered migration a chosen path to reduce the family's vulnerability to income, food, health, and other human insecurities. Thus, remittance, which is the primary outcome from migration, can directly affect the household's capacity to be less vulnerable to shocks and resilience. Studies show that migration is a household-level strategy that allows them to spread the risk of environmental stressors and potentially builds adaptive capacity. Previous research $[11,17,18,36]$ demonstrated that migrant remittances could help migrant families and origin communities in environmentally vulnerable areas by accumulating savings and asset creation; livelihood diversification.

The migrant remittances also improved access to food across seasons; acquisition of new knowledge, skills, and resources, creating, extending, and consolidating social networks across regions; or providing a safety net in times of extreme weather events. ${ }^{1}$ Therefore remittances receiving households perceive climate impact, vulnerability, and resilience differently. We can assume that households that receive cash transfers will be less climate-risk, less vulnerable, and more be resilient to environmental disasters than non-remittance households. There are two assumptions in this literature. In the optimist view, remittances are expected to help households in adaptative strategies and anticipate the impacts of natural disasters in the future [38]. Second, the pessimist view argues that households who migrate and send remittances failed to build healthy adaptative strategies [60-63].

In terms of empirical evidence, studies have concluded that remittances increase significantly in times of economic crisis, political conflicts, and disasters [19, 49,64]. In this perspective, [64] uses empirical analysis to examine the impact of foreign remittances and some other variables (foreign aid, debt, human capital, inflation, and income) on poverty alleviation in 39 countries, including the lower middle, upper-middle, and high-income countries. They find that increase in revenue leads to a decrease in poverty.

Musakwa and Odhiambo [65] use time-series data from 1980 to 2017 to conclude that remittances play an important role in driving poverty reduction in Botswana, irrespective of whether poverty is measured household consumption expenditure or infant mortality rate $[16,17]$ demonstrate that remittances are countercyclical and serve as a safety net for households with migrants abroad. On the other hand, [66] suggests that remittances allow households to absorb shocks and cope with unexpected expenses. In this context, remittances would be a form of self-insurance for households $[19,67]$.

In summary, there is a growing consensus that remittances are a powerful ex-post mechanism to help households cope with and recover from disasters $[17,18,36,68]$. The few empirical studies that have explored the role of remittances

\footnotetext{
1 Extracted from the literature review of Banerjee et al. (2017).
} 
in emergencies and disaster recovery $[17,21,27,37]$ suggest that migrants respond faster than international aid help their relatives [16]. For example, [16] show that in Sri Lanka, migrants were significantly quicker than the Government in supporting their families at the time of the 2004 tsunami. Similarly, in the 2004 tsunami, [49] observes that remittance recipients' recovery time in Aceh, Indonesia, was faster than non-recipients. Also, [66] reveal that remittance recipient households were less vulnerable after the 2005 North Pakistan earthquake than non-recipients. Remittance recipients could repair and rebuild their houses more quickly than those who did not have access to these resources.

Moreover, the study concludes that migrant remittances strengthened recipients' resilience when some non-recipients gave up their assets to cope with the shock [66]. However, underscoring the dependence on remittances, [49] notes that in the first months after the 2004 tsunami, remittance-dependent households were as affected as those who did not receive remittances most dependent were unable to meet their daily consumption needs. This observation shows that the influence of migrant remittances on vulnerability is not homogeneous among recipients. It depends on the degree of dependency and, therefore, would vary from one country to another. Le De et al. [27] show that the more governments facilitate the networks through which remittances are made, the more significant the most exposed effect would be. In Togo's framework, we hypothesize that remittances from migrants play a role in cushioning the impacts of climate change on household living standards, reducing their vulnerability, and strengthening their resilience.

\section{Methodological approach}

\subsection{Analytical framework and empirical model}

The dependent variable is climate change and is a binary variable that is measured in three different ways. At first, climate change takes the value 1 if the impact of climate change is very high or high and 0 otherwise. In the second approach, the binary dependent variable is based on the household's perception of vulnerability and takes the value 1 if it feels vulnerable to climate change and 0 otherwise. Finally, the climate shock measurement is based on the household's perception of resilience and takes the value 1 if the household feels resilient to climate change and 0 otherwise. Because the dependent variable remains a binary variable, regardless of the measurement used, we employ a Probit model assuming that households' perceptions of climate-related risk follow a normal distribution. There are three advantages in assuming a normal distribution of the household perception function. First, because of the normality of errors in the Probit model, economists prefer it to the logit model [69]. Second, non-linear probability models specification is more comfortable with Probit models because of the normal distribution properties [69]. Furthermore, [70] shows that there is no difference in performance between Probit and Logit models because both are estimated by the Maximum Likelihood method. Finally, the Probit model's likelihood is higher than that of the Logit model in the case of this study showing that the Probit model seems to be more adequate to our data than the Logit model.

Let $G$ be the distribution function of the standard normal distribution law, which is written as follows:

$$
G(z)=\phi(z) \equiv \int_{-\infty}^{z} \emptyset(v) d v
$$

where $\emptyset(v)=(2 \pi)^{-1 / 2} \exp \left(-z^{2} / 2\right)$ is the density function for a standard normal distribution.

The underlying latent variable model $\left(y^{*}\right)$ is written as follow:

$$
y^{*}=\beta_{0}+x_{i} \beta+e, y=1\left[y^{*}>0\right]
$$

With $y^{*}$ the unobserved variable whose proxy used is either the impact of climate change, vulnerability or resilience of the household to climate change threats, $x_{i}$ a vector of explanatory variables, $\beta_{0}$ and $\beta$ are the parameters to be estimated and $e$ the error term independent of $x_{i}$, symmetrical about 0 and normally distributed. $y$ is 1 if $y^{*}>0$ and zero if $y^{*} \leq 0$ and the probability of response under the above assumptions can be written as:

$$
P(y=1 \mid x)=P\left(y^{*}>0 \mid x_{i}\right)=G\left(\beta_{0}+x_{i} \beta_{i}\right)
$$

To estimate the marginal effect of the different explanatory variables $x_{i}$ on the likelihood of households being positively impacted, weakly impacted, vulnerable or resilient to changes in household climate $P(y=1 \mid x)$, the empirical model is rewritten as follows: 


$$
\begin{aligned}
P(\text { Climat }=1 \mid x)= & G\left(\beta_{0}+\beta_{1} \text { age }+\beta_{2} \text { age }{ }^{2}+\beta_{3} \text { gender }+\beta_{4} \text { eucation }+\beta_{5} \text { north }+\beta_{6} \log (\text { Income })\right. \\
& +\beta_{7} \text { unemployed }+\beta_{8} \log (\text { expensespercapita })+\beta_{9} \text { watersource }+\beta_{10} \text { energysource } \\
& \left.+\beta_{11} \text { flood }+\beta_{13} \text { drought }\right)
\end{aligned}
$$

From the above specification, marginal effects are deducted. Thus, the marginal effect of age on the impact, vulnerability, and revealed the resilience of households is:

$$
\partial P(y=1 \mid x) / \partial a g e=g\left(\beta_{0}+x \beta\right)\left(\beta_{1}+2 \beta_{2} \text { age }\right)
$$

The marginal effect of gender on this probability is:

$$
\partial P=(y=1 \mid x) / \partial \text { gender }=\mathrm{g}\left(\beta_{0}+x \beta\right) \beta_{3}
$$

The marginal effects of the variable's education, region, unemployment, water, and energy sources, flooding, and drought are respectively:

$$
\begin{gathered}
\partial \mathrm{P}(\mathrm{y}=1 \mid \mathrm{x}) / \partial \text { education }=g\left(\beta_{0}+x \beta\right) \beta_{4} \\
\partial \mathrm{P}(\mathrm{y}=1 \mid \mathrm{x}) / \partial \text { north }=g\left(\beta_{0}+x \beta\right) \beta_{5} \\
\partial \mathrm{P}(\mathrm{y}=1 \mid \mathrm{x}) / \partial \text { unemployed }=\mathrm{g}\left(\beta_{0}+x \beta\right) \beta_{7} \\
\partial P(\mathrm{y}=1 \mid \mathrm{x}) / \partial \text { water }=\mathrm{g}\left(\beta_{0}+x \beta\right) \beta_{8} \\
\partial \mathrm{P}(\mathrm{y}=1 \mid \mathrm{x}) / \partial \text { energy source }=\mathrm{g}\left(\beta_{0}+x \beta\right) \beta_{9} \\
\partial \mathrm{P}(\mathrm{y}=1 \mid \mathrm{x}) / \partial \text { flood }=\mathrm{g}\left(\beta_{0}+x \beta\right) \beta_{11} \\
\partial \mathrm{P}(\mathrm{y}=1 \mid \mathrm{x}) / \partial \mathrm{drought}=\mathrm{g}\left(\beta_{0}+x \beta\right) \beta_{12}
\end{gathered}
$$

The marginal effects of per capita income and expenditures on the likelihood of being impacted, vulnerable, and resilient to climate change are:

$$
\begin{gathered}
\partial \mathrm{P}(\mathrm{y}=1 \mid \mathrm{x}) / \text { income }=\mathrm{g}\left(\beta_{0}+x \beta\right)\left(\frac{\beta_{6}}{\text { income }}\right) \\
\partial \mathrm{P}(\mathrm{y}=1 \mid \mathrm{x}) / \text { dexpense per capita }=\mathrm{g}\left(\beta_{0}+x \beta\right)\left(\frac{\beta_{8}}{\text { expensespercapita }}\right)
\end{gathered}
$$

These calculated marginal effects and elasticities of the probability of response concerning the explanatory variables will make it possible to estimate their impacts on household perceptions of climate impact.

\subsection{Methodology}

First, we estimate our model using the Maximum Likelihood method (MLE), which automatically considers the heteroskedasticity problem and assumes the error's probability distribution. Moreover, since the Probit model is a non-linear model, Ordinary Least Squares (OLS), two-stage Least Squares (2SLS), or Weighted Least Squares (WLS) are not applicable [69]. However, the MLE estimator's general theory shows that it is convergent, asymptotically normal efficient [69].

The probability distribution of households' perceptions of impacts, vulnerability, and resilience to climate change impacts $y_{i}$ conditionally to the explanatory variables $x_{i}$ is described as follows: 


$$
f\left(y \mid x_{i} ; \beta\right)=\left[G\left(x_{i} \beta\right)\right]^{y}\left[1-G\left(x_{i} \beta\right)\right]^{1-y}, y=0,1
$$

The log-likelihood function for our sample is calculated as follows:

$$
\varphi(\beta)=\sum_{i=1}^{n} y_{i} \log \left[G\left(x_{i} \beta\right)\right]+\left(1-y_{i}\right) \log \left[1-G\left(x_{i} \beta\right)\right]
$$

The estimator $\widehat{\beta}_{i}$ obtained by maximizing this log-likelihood function is convergent, asymptotically normal, and efficient [69].

\subsubsection{Coping with selection bias: propensity score method}

We adopt a propensity score framework to derive cash transfers' impact on households' vulnerability and resilience to climate change. Since it's possible to distinguish families who receive cash transfers (remittances) from those who do not, it's necessary to consider unobserved characteristics inherent to families with migrants that are unobservable through the survey data. Furthermore, our data did not allow using a fixed Effect Method or Difference in Difference, ${ }^{2}$ which can cope with selection bias due to heterogeneity among households. We employ propensity score matching (PSM) as an alternative approach and implement various matching methods for robustness checking [71-73].

The method's idea is to match treated households with untreated ones with similar values for the characteristics that we have found to be the determinants of cash transfers. The Propensity score matching framework is used.

According to the approach of [74], for each household $i$, with $i=1,2, \ldots, N$, the treatment effect, $\Delta_{i}$, can be defined as the difference between "treated" and "untreated":

$$
\Delta_{i}=Y_{1 i}-Y_{0 i}
$$

where $Y_{1 i}$ and $Y_{0 i}$ represents the potential outcomes for treated and non-treated households, respectively. For each unit (households) $i$, it's only possible to observe one result, while the other is the counterfactual scenario that cannot be obtained from the data.

Following [75] replicated by [76], we can modify Eq. 1 in such a way to allow estimating the average treatment effect on the treated (ATT) that we can formally express as follow:

$$
A T T=(\Delta \mid Z=1)=E\left(Y_{1} \mid Z=1\right)-E\left(Y_{0} \mid Z=1\right)
$$

With ATT, the difference between the potential outcome with and without treatment for households that receive treatment and $Z$, an indicator variable of the state ( $Z=1$ when the treatment is received and $Z=0$ when not).

One problem in Eq. 2 is unobservability. In fact, without additional assumptions, we will not be able to estimate $E\left(Y_{0} \mid Z=1\right)$, which indicates the hypothetical outcome that would have been obtained if the treated had not received cash transfers. We can rewrite Eq. 2 like follows:

$$
E\left(Y_{1} \mid Z=1\right)-E\left(Y_{0} \mid Z=1\right)=A T T-\left[E\left(Y_{0} \mid Z=0\right)-E\left(Y_{0} \mid Z=1\right]\right.
$$

where $E\left(Y_{1} \mid Z=1\right)$ and $E\left(Y_{0} \mid Z=0\right)$ can be estimated; nevertheless, these do not provide the ATT. Besides, we can only estimate this effect when the bias is zero, i.e., $E\left(Y_{0} \mid Z=1\right)-E\left(Y_{0} \mid Z=0\right)=0$. However, when using non-experimental data as in our case, this condition generally does not hold because the variables that explain the participation decision also contribute to determining the outcome variable [76]. Consequently, the treated household's outcome will be different even in the absence of the treatment, leading to a self-selection bias problem.

The literature recommends the propensity score matching (PSM) method to deal with such bias and get unbiased and robust ATT estimates [77]. This method's backbone is to identify an adequate number of candidates that closely resemble the beneficiary households in the control group. Based on the estimated propensity score, we will evaluate the impact of cash transfers on households' vulnerability and resilience to climate change impacts. Two fundamental assumptions are required when using the PSM method: Exogeneity of the treatment and overlap.

\footnotetext{
2 To apply the diff-in-diffs estimator, at least one pre-programme set and one post-programme set of observations are required. This is not possible with our data. We have one set of data which can be considered as a post-programme data.
} 
The first exogeneity assumption implies that the difference in potential outcomes (Vulnerability and resilience) - with and without treatment-is due only to the treatment conditional on a vector of the covariate (X). Moreover, the set of covariates in this vector is not affected by the treatment, and it is assumed that it has been captured in the model. This means that there are no omitted variables. Formally, this first assumption can be expressed as follows:

$$
\left\{Y_{0}, Y_{1}\right\} \perp Z \mid X
$$

According to [78], the overlap assumption assumes the perfect predictability of participation on vector X. It guarantees that all households with the same characteristics within the sample have a positive probability of being treated or untreated. Formally, it can be expressed as follows:

$$
0<P(Z=1 \mid X)<1
$$

The ATT can now be estimated using Propensity Score Matching (PSM), which solves dimensionality problems when $X$ has too many components. [79] defined propensity scores as a function that estimates the probability of receiving the treatment given the vector of covariates $X$, previously observed:

$$
\theta(X)=P(Z=1 \mid X)
$$

This means that $\mathrm{X}$ is being summarized into a single number $\theta$. To estimate $\theta$, one can use the probit or logit model to predict the probability that a household has access to credit based on its characteristics. According to [79], we can show that the propensity score estimated satisfies the exogeneity and overlap assumption. Therefore, the PSM estimator of ATT is more biased and can be written as follows:

$$
A^{A T T^{P S M}}=E_{\theta(X) \mid Z=1}\left[E\left(Y_{1} \mid Z=1, \theta(X)\right)-E\left(Y_{0} \mid Z=1, \theta(X)\right)\right]
$$

Several authors $[80,81]$; listed several matching algorithms that can be used to estimate the ATT. In our case, we report the results for four of them: Nearest neighbor, stratification, radius, and kernel matching. This allows us to compare the results and test the estimated impacts of cash transfers on household climate vulnerability and resilience.

To verify the results' robustness, we used the sensitivity analysis proposed by [82] and the bounding approach proposed by [83] Mantel-Haenszel Statistic. This approach allows us to address unobserved variables that can simultaneously affect assignment into treatment and the outcome variable.

\subsubsection{Coping with endogeneity: instrumental variable regression}

The PSM method accounts for selection bias but does not consider that remittance decisions by migrants are endogenous and therefore need to be controlled to have unbiased estimates. Consequently, w, therefore, undertook estimation by instrumental variable. We considered two instruments following the work of [84]:

- Unemployment in 2015: this dummy variable specifies whether the head of household is unemployed or not. The idea is that this variable is exogenous and can influence the migrant's decision to send money to the household [84].

- The number of older people in the household: The argument behind this variable is related to the concept of altruism as a motive to send remittances by migrants, as demonstrated by [85] and [86]. As a result, having a household with more older adults may influence migrant's decision to send money to cover these members' health expenses and decrease their productivity [87]. First, we present the instruments' joint results on climate-related risk, vulnerability, resilience, and migrant remittances. The idea is to test these instruments' joint relevance in explaining the variable assumed to be endogenous (migrant remittances). Second, by estimating the instruments' effects on the outcome variables (climate impact, vulnerability, and resilience), we test whether the instruments are not correlated with these outcome variables, another condition for the instruments valid. The following section presents the data used for the econometric estimates. 


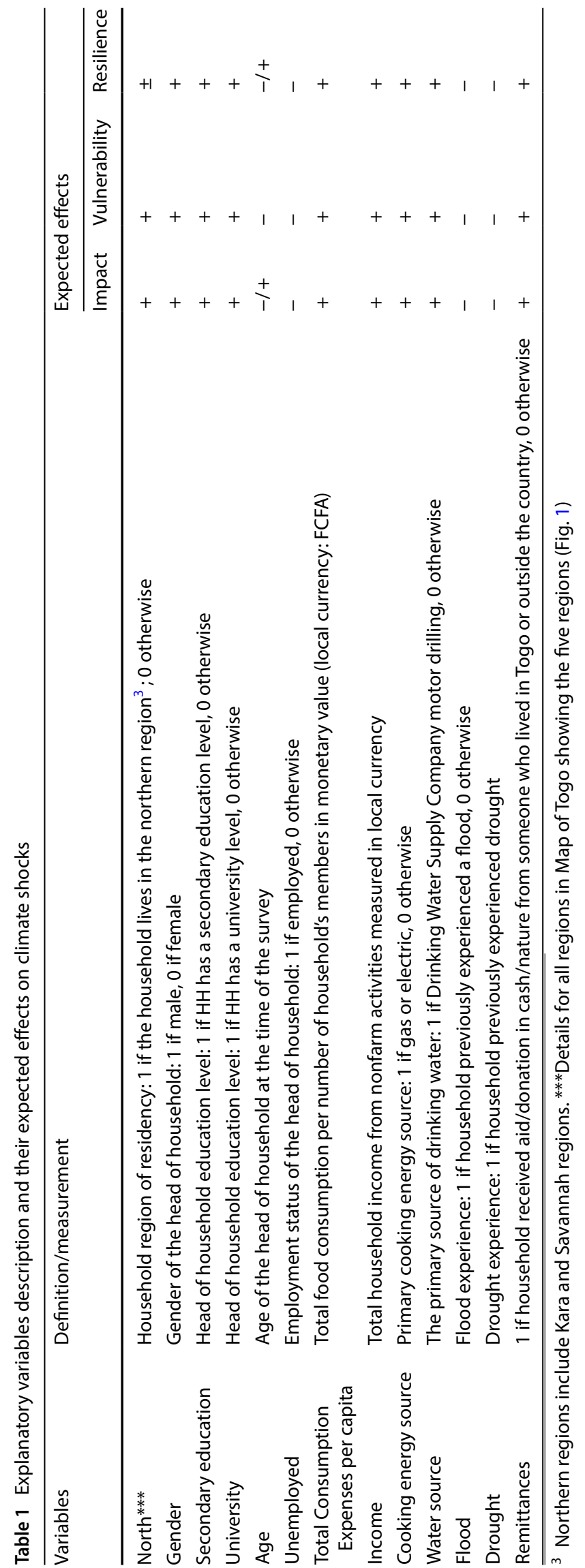




\section{Data analysis}

\subsection{Descriptions of data and variables}

The data used in this paper come from The Unified Survey of Basic Well-being Indicators (QUIBB) conducted in 2015 by the National Institute of Economic and Demographic Studies (INSEED) of Togo. Covering a sample of 2,370 households, the varied information collected provides information on the composition of household expenditure, sources of income, the effects of climatic shocks, and other risks and survival strategies. The survey also includes information on the sociodemographic characteristics of households and food security. Our study involves analyses of climate impacts, vulnerability, and resilience of households. The survey analysis shows that the approach used is a subjective one where respondents assessed these different variables without the interviewing agents' involvement. In this paper, we do not engage in any calculation of indicators to measure these climate variables. The data collected offer three scales of appreciation for climate impact (very high, high, and moderate) and two scales of analysis for vulnerability and resilience (vulnerable or not, resilient or not). Therefore, we have reduced the analysis scale to two for the climate-related impact variable (Very High and Low) and maintained the other variables' scale for simplification reasons.

Our independent variable called climate change is measured in three ways: climate change impact, climate vulnerability, and climate resilience. The full description of the independent variables is presented in Table 1.

\subsection{Descriptive statistics}

Table 2 below presents statistics of all the variables included in our models.

\subsubsection{Climate-related-risk and household livelihoods}

Figure 2 shows the perceived threats from climate change on households' living standards across different country regions. We find that more than $80 \%$ of households indicate that climate threats would affect their living conditions more severely or severely. An analysis by the residency region shows that the plateau region is where households seem to be more threatened (92.54\%) than $77.31 \%$ in greater Lome. These results can be explained by the fact that most agricultural activities in the country are focused on the plateau region, which is highly dependent on climate, as is the case in many developing countries.

The low perception of climate threats to household living conditions in the savannah compared to other regions can also be explained by the fact that this region is mostly desert and where households are used to a less favorable climate. This experience of living in a desert environment may influence their perception of future climate change.

We have also divided the country into two major regions, the north, and the south. Our results did not show a significant difference in households' perceptions of the climatic events' impact on their living conditions between the south and the north. Indeed, $88.87 \%$ of households in the South perceive climate-related risk effects on their living standard as very high or high compared to $85.27 \%$ in the North. This means that, even if the South's climate is more favorable than in the North, households in the North may develop skills in coping with climatic events and thus, less perceive climate related-risks.

As indicated above, since the South's climate is more favorable than in the North, households in the South may perceive climate change more quickly than households in the North (Fig. 3). These results confirm those found by [88] in Togo.

\subsubsection{Household vulnerability to climate change}

Figure 4 shows the level of households' climate vulnerability by region. More than $50 \%$ of households in the north indicate that they are vulnerable to climate change, compared to $47.34 \%$ in the south. This result is expected and consistent with the households' perceptions of how climate shocks impact their living conditions.

Moreover, this region is home to most of the country's poor households [89], which are generally the most vulnerable to climate change [88]. One implication of this result is that the most vulnerable households to climate change reside in the country's most arid areas. These findings are consistent with those found in Ghana, where farmers were living in the country's northern zone report being highly vulnerable to climate [40,90]. 
Table 2 Descriptive statistics of all variables

\begin{tabular}{|c|c|c|c|c|c|}
\hline \multirow[t]{2}{*}{ Variables } & (1) & (2) & (3) & (4) & (5) \\
\hline & Observations & Mean & $\begin{array}{l}\text { Standard } \\
\text { deviation }\end{array}$ & Minimum & Maximum \\
\hline Remittances & 2335 & 0.248 & 0.432 & 0 & 1 \\
\hline External remittances & 2335 & 0.0330 & 0.179 & 0 & 1 \\
\hline Internal remittances & 2335 & 0.215 & 0.411 & 0 & 1 \\
\hline High climate related-risk & 2335 & 0.555 & 0.702 & 0 & 1 \\
\hline Low climate related-risk & 2335 & 0.0441 & 0.205 & 0 & 1 \\
\hline Vulnerability & 2335 & 0.0681 & 0.252 & 0 & 1 \\
\hline Resilience & 2335 & 0.1619 & 0.368 & 0 & 1 \\
\hline Household head age & 2323 & 44.62 & 15.38 & 14 & 98 \\
\hline Age square & 2323 & 2.228 & 1.599 & 196 & 9,604 \\
\hline Rooms & 2319 & 2.437 & 1.696 & 1 & 19 \\
\hline Household Size & 2335 & 4.618 & 2.925 & 1 & 25 \\
\hline Size square & 2335 & 29.88 & 42.28 & 1 & 625 \\
\hline Lome & 2335 & 0.329 & 0.470 & 0 & 1 \\
\hline Maritime & 2335 & 0.133 & 0.339 & 0 & 1 \\
\hline Plateau & 2335 & 0.170 & 0.376 & 0 & 1 \\
\hline Central & 2335 & 0.108 & 0.311 & 0 & 1 \\
\hline Kara & 2335 & 0.136 & 0.343 & 0 & 1 \\
\hline Savane & 2335 & 0.123 & 0.329 & 0 & 1 \\
\hline Location (Urban = 1) & 2335 & 0.661 & 0.474 & 0 & 1 \\
\hline Primary education & 2335 & 0.259 & 0.438 & 0 & 1 \\
\hline Secondary education & 2335 & 0.376 & 0.484 & 0 & 1 \\
\hline University education & 2335 & 0.0861 & 0.281 & 0 & 1 \\
\hline Water source & 2335 & 0.390 & 0.488 & 0 & 1 \\
\hline Cooking Energy source & 2335 & 0.101 & 0.301 & 0 & 1 \\
\hline Salaried employed & 2335 & 0.242 & 0.428 & 0 & 1 \\
\hline Farmer & 2335 & 0.0771 & 0.267 & 0 & 1 \\
\hline Other self-employed & 2335 & 0.244 & 0.429 & 0 & 1 \\
\hline Inactive & 2335 & 0.0938 & 0.292 & 0 & 1 \\
\hline Unemployed & 2335 & 0.0274 & 0.163 & 0 & 1 \\
\hline Marital Status & 2335 & 0.146 & 0.354 & 0 & 1 \\
\hline Drought & 2335 & 0.0552 & 0.229 & 0 & 1 \\
\hline Flood & 2335 & 0.0557 & 0.229 & 0 & 1 \\
\hline Gender & 2335 & 0.257 & 0.437 & 0 & 1 \\
\hline Rich & 2335 & 0.556 & 0.497 & 0 & 1 \\
\hline Log (income) & 2335 & 5.228 & 5.459 & 0 & 15.425 \\
\hline Log (expense per capita) & 2335 & 12.3507 & 0.8196 & 8.6484 & 14.922 \\
\hline Older & 2335 & 0.152 & 0.360 & 0 & 1 \\
\hline
\end{tabular}

\subsubsection{Households perceived resilience to climate change}

Figure 5 below shows the degree of resilience of households to climatic events by region. $49.96 \%$ of households residing in the southern region estimate that they are resilient to climate change compared to $50.05 \%$ of households in the northern region. As mentioned above, even with the least favorable climatic conditions, more poor households [89], the north region is as resilient as the south region. 
Fig. 1 Map of Togo showing the five regions. Online Project (http://www.nationsonl ine.org/). Own depiction for the five regions

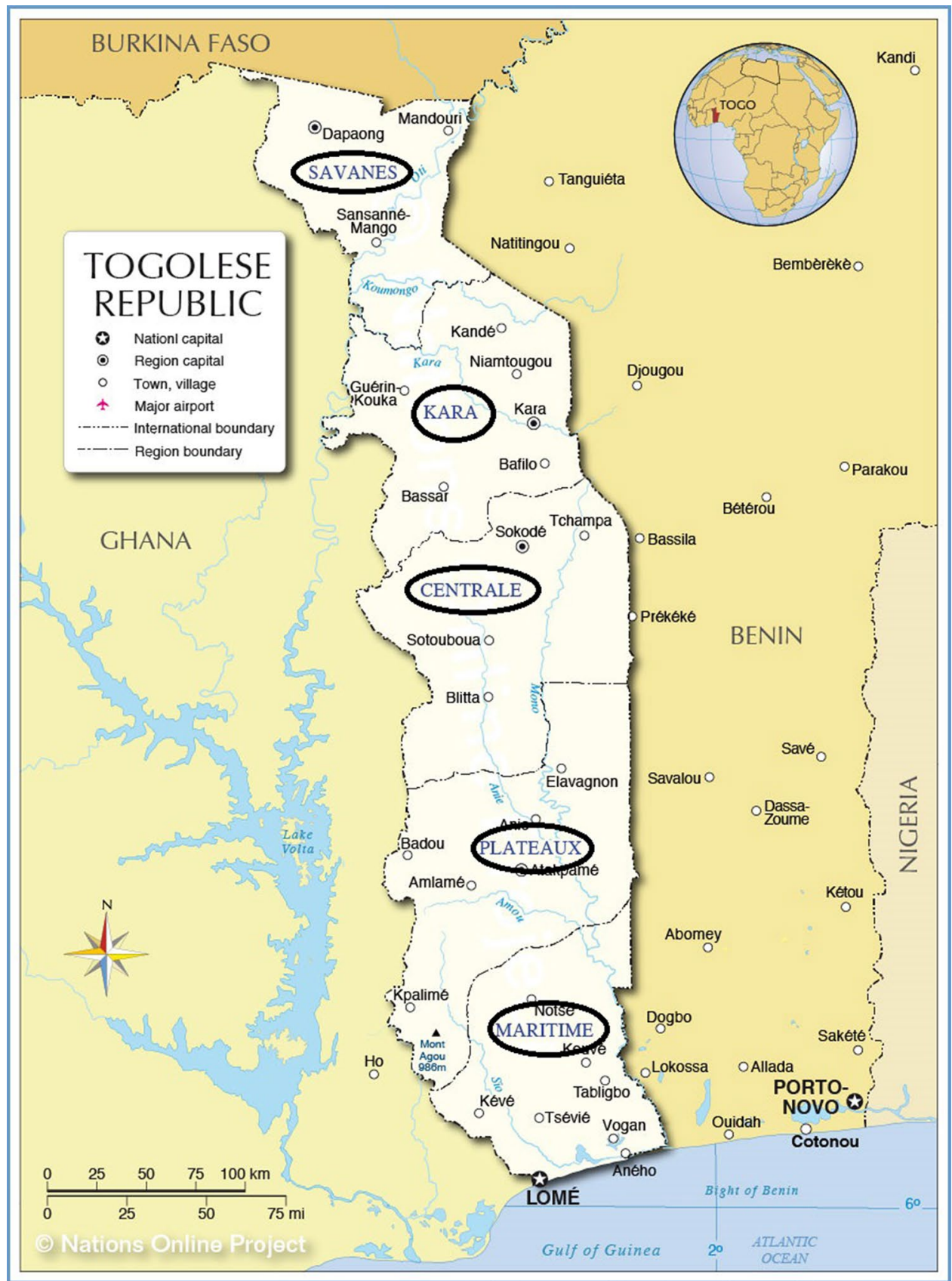

\section{Results and discussion}

\subsection{Determinants of the perceived impact of climate change on households' standards of living}

Table 3 presents the determinants of perceived households' impacts of climate shocks on livelihoods. The results show that age, gender, per capita expenditure, energy, and water sources are significantly correlated with climate change's perceived impact.

Age has the expected positive effect on the perceived impact of climate change on household living standards. Still, the relationship is not linear because the quadratic term is statistically significant at the $1 \%$ level. This means an age threshold above which households perceive fewer climate threats on their living standards. It implies that younger people believe they are more exposed to climate threats than older people. A learning effect can be inferred at this level. Indeed, 
Fig. 2 Climate shocks and households 'livelihoods by regions of Togo. Source:

Authors from the QUIBB [89]

Fig. 3 Climate changes threaten and households' livelihoods: North vs. South. Source: Authors, from QUIBB [89]

Fig. 4 Households' vulnerability to climate change: North vs. South. Source: authors from QUIBB [89]
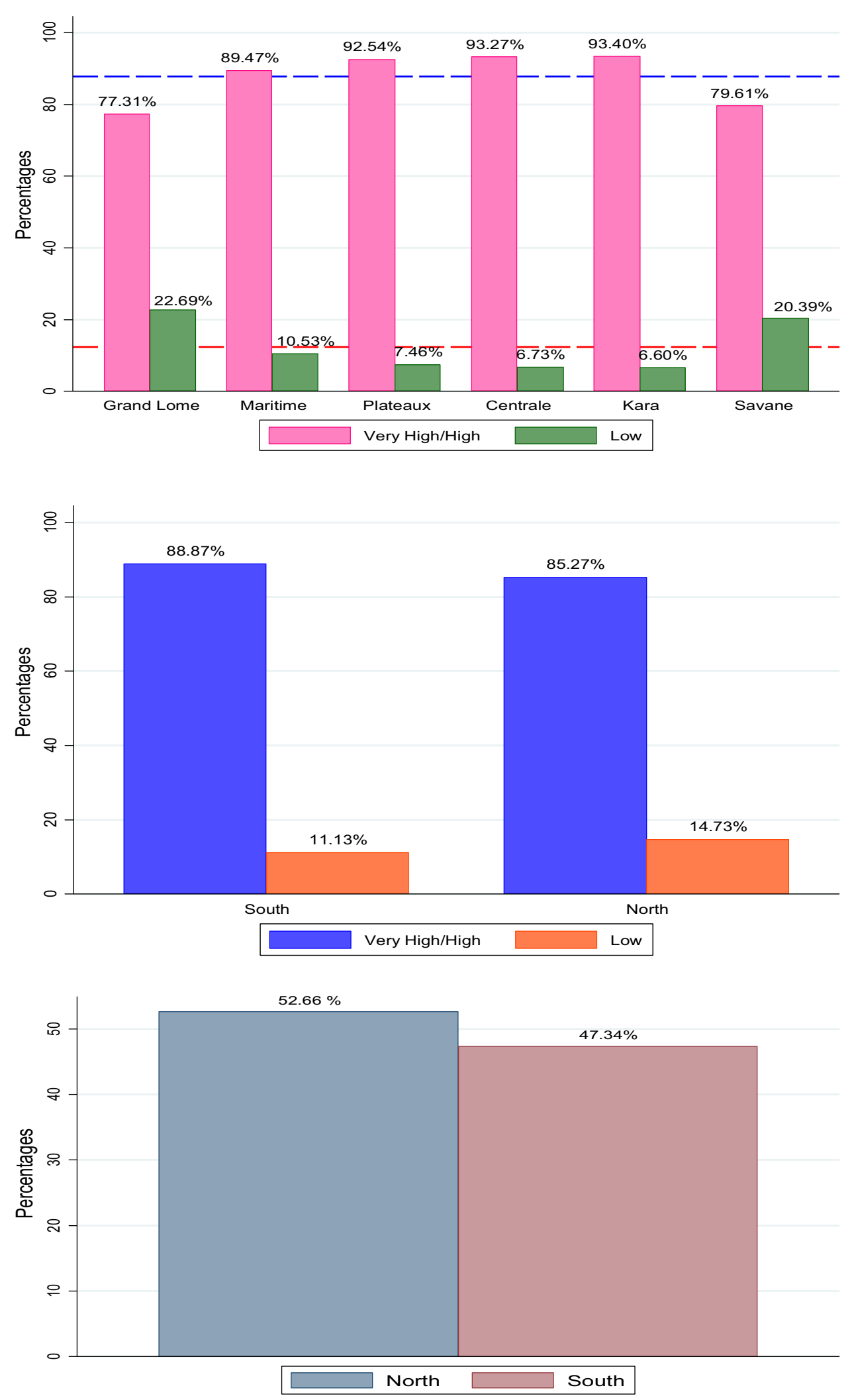

younger people have less experience in dealing with climate-related effects on their standard of living. However, from a given age onwards, these young people gain knowledge, adapt, and develop strategies to respond to climate-related risk. As a result, as age increases, households respond better to the impact of climate change on their living standards. 
Fig. 5 Households resilience to climate-related risk by regions. Source: authors from QUIBB [89]

Table 3 Effects of climate changes on households' livelihood

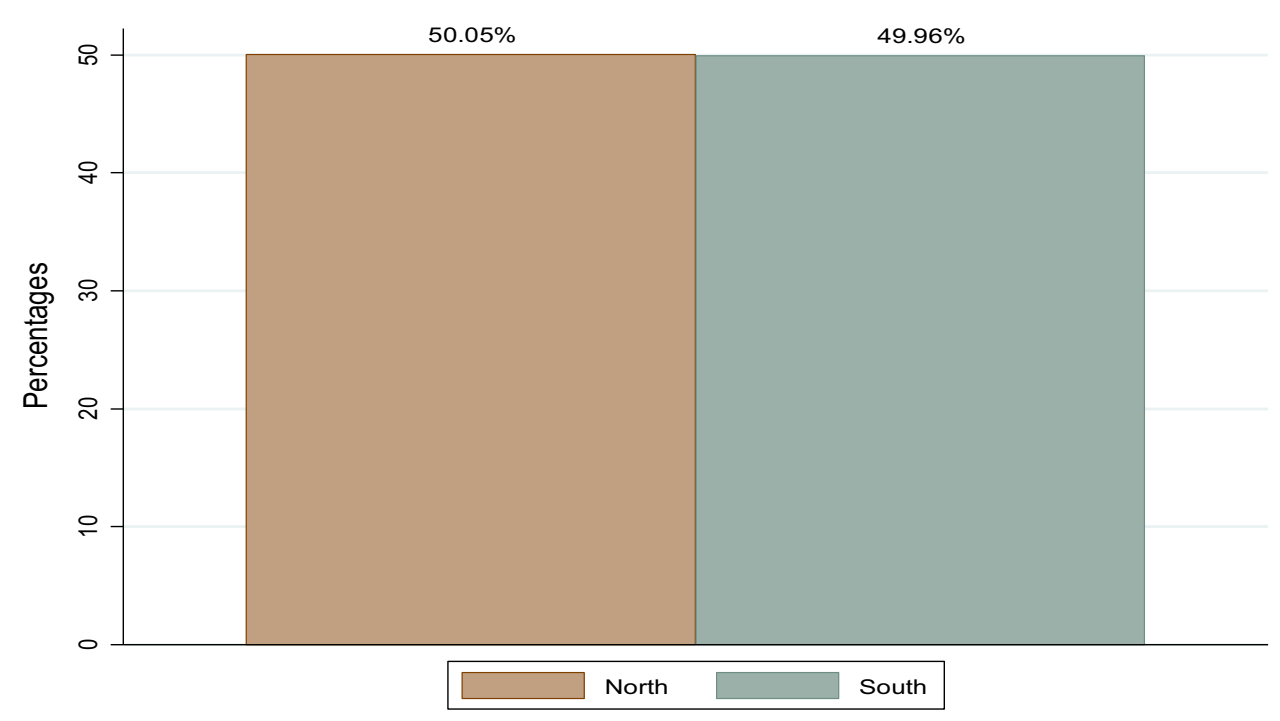

\begin{tabular}{|c|c|c|}
\hline \multirow[t]{2}{*}{ Variables } & (1) & (2) \\
\hline & High & Low \\
\hline \multirow[t]{2}{*}{ Age } & $0.0474^{* * *}$ & $0.0594 * * *$ \\
\hline & $(0.0120)$ & $(0.0222)$ \\
\hline \multirow[t]{2}{*}{ Age square } & $-0.000344^{* * *}$ & $-0.000560^{* *}$ \\
\hline & $(0.000116)$ & $(0.000226)$ \\
\hline \multirow[t]{2}{*}{ North region } & 0.0486 & 0.0103 \\
\hline & $(0.0845)$ & $(0.145)$ \\
\hline \multirow[t]{2}{*}{ Secondary education } & -0.0738 & -0.0453 \\
\hline & $(0.0787)$ & $(0.139)$ \\
\hline \multirow[t]{2}{*}{ University education } & -0.193 & -0.164 \\
\hline & $(0.143)$ & $(0.260)$ \\
\hline \multirow[t]{2}{*}{ Gender $(\operatorname{Man}=1)$} & $0.224^{* *}$ & 0.00272 \\
\hline & $(0.0889)$ & $(0.146)$ \\
\hline \multirow[t]{2}{*}{ Unemployment } & -0.0300 & 0.205 \\
\hline & $(0.207)$ & $(0.359)$ \\
\hline \multirow[t]{2}{*}{ Expenses per capita } & $-0.131^{* * *}$ & $-0.135^{*}$ \\
\hline & $(0.0454)$ & $(0.0736)$ \\
\hline \multirow[t]{2}{*}{ Income } & $-0.0113^{*}$ & -0.0147 \\
\hline & $(0.00671)$ & $(0.0117)$ \\
\hline \multirow[t]{2}{*}{ Flood } & 0.0891 & 0.0378 \\
\hline & $(0.158)$ & $(0.275)$ \\
\hline \multirow[t]{2}{*}{ Drought } & 0.134 & -0.189 \\
\hline & $(0.166)$ & $(0.325)$ \\
\hline \multirow[t]{2}{*}{ Energy source } & $-0.580^{* * *}$ & $-0.634^{*}$ \\
\hline & $(0.147)$ & $(0.345)$ \\
\hline \multirow[t]{2}{*}{ Water source } & $-0.353^{* * *}$ & -0.136 \\
\hline & $(0.0764)$ & $(0.136)$ \\
\hline \multirow[t]{2}{*}{ Constant } & -0.112 & -1.374 \\
\hline & $(0.642)$ & $(1.045)$ \\
\hline Observations & 1368 & 1368 \\
\hline
\end{tabular}

Robust standards errors in parentheses; ${ }^{* * *} p<0.01,{ }^{* *} p<0.05,{ }^{*} p<0.1$ 
Table 4 Determinants of households perceived vulnerability to climaterelated risk

\begin{tabular}{|c|c|}
\hline Variables & $\begin{array}{l}\text { (1) } \\
\text { Vulnerability }\end{array}$ \\
\hline Age of $\mathrm{HH}$ & $\begin{array}{l}-0.00931 \\
(0.0165)\end{array}$ \\
\hline Age square & $\begin{array}{l}0.000145 \\
(0.000155)\end{array}$ \\
\hline North region & $\begin{array}{l}-0.127 \\
(0.130)\end{array}$ \\
\hline Secondary education & $\begin{array}{l}0.00332 \\
(0.118)\end{array}$ \\
\hline University education & $\begin{array}{l}0.255 \\
(0.171)\end{array}$ \\
\hline Male & $\begin{array}{l}0.103 \\
(0.126)\end{array}$ \\
\hline Unemployment & $\begin{array}{l}0.120 \\
(0.306)\end{array}$ \\
\hline Expenses per capita & $\begin{array}{l}0.00613 \\
(0.0639)\end{array}$ \\
\hline Income & $\begin{array}{l}0.0166^{*} \\
(0.00950)\end{array}$ \\
\hline Flood & $\begin{array}{l}0.461^{* *} \\
(0.188)\end{array}$ \\
\hline Drought & $\begin{array}{l}-0.641 \\
(0.401)\end{array}$ \\
\hline Energy source & $\begin{array}{l}-0.106 \\
(0.180)\end{array}$ \\
\hline Water source & $\begin{array}{l}-0.174 \\
(0.113)\end{array}$ \\
\hline Constant & $\begin{array}{l}-1.610^{*} \\
(0.865)\end{array}$ \\
\hline Observations & 1368 \\
\hline
\end{tabular}

Robust standards errors in parentheses; ${ }^{* * *} p<0.01,{ }^{* *} p<0.05,{ }^{*} p<0.1$

The positive effect of the male gender on the perceived impact of climate change is expected an expected result. Indeed, men are more engaged in more dependent activities on the climate, such as agriculture, fishing, etc. Simultaneously, most Togo women, who are in businesses, do not heavily rely on climate effects. As a result, this social stratum seems to be the most affected and would have a higher perception of climate-related risk on living standards.

Three other indicators reflecting the wellbeing of households have the expected negative sign. According to our results, per capita household expenditure, the use of gas and electricity as a source of energy for cooking, and a drinking water source reduce the effects of climate change on households' living standards. One implication of these results is that households with a high level of wellbeing tend to perceive climate related-risks as a moderate threat.

Climate variables such as drought and flood are not statistically significant but show the expected positive sign. This suggests that extreme climatic events amplify the perceived adverse effects of climate change on households' living standards.

\subsection{Determinants of households perceived vulnerability to the impacts of climate change}

We then estimated the factors that explain households' perceived vulnerability to climate change, and the results are presented in Table 4. Factors that significantly influence the household's perceived vulnerability to climate change are income, drought, and floods. Household income has a positive effect on vulnerability to climate change. This means that as households' income increases, the likelihood of becoming less vulnerable to climate change increases as well. 
Table 5 Determinants of household's resilience to climate changes

\begin{tabular}{|c|c|}
\hline Variables & $\begin{array}{l}\text { (1) } \\
\text { Resilience }\end{array}$ \\
\hline Household head age & $\begin{array}{l}0.0173 \\
(0.0166)\end{array}$ \\
\hline Age square & $\begin{array}{c}-0.000212 \\
(0.000156)\end{array}$ \\
\hline North region & $\begin{array}{l}0.152 \\
(0.137)\end{array}$ \\
\hline Secondary education & $\begin{array}{l}-0.0230 \\
(0.122)\end{array}$ \\
\hline University education & $\begin{array}{l}-0.272 \\
(0.177)\end{array}$ \\
\hline Male & $\begin{array}{l}-0.0723 \\
(0.128)\end{array}$ \\
\hline Unemployment & $\begin{array}{c}-0.163 \\
(0.308)\end{array}$ \\
\hline Expense per capita & $\begin{array}{l}0.00650 \\
(0.0669)\end{array}$ \\
\hline Income & $\begin{array}{l}-0.0213^{* *} \\
(0.00980)\end{array}$ \\
\hline Flood & $\begin{array}{l}-0.444^{* *} \\
(0.195)\end{array}$ \\
\hline Drought & $\begin{array}{l}-0.587^{* * *} \\
(0.401)\end{array}$ \\
\hline Energy source & $\begin{array}{l}0.0739 \\
(0.181)\end{array}$ \\
\hline Water source & $\begin{array}{l}0.156 \\
(0.116)\end{array}$ \\
\hline Constant & $\begin{array}{l}1.317 \\
(0.896)\end{array}$ \\
\hline Observations & 1368 \\
\hline
\end{tabular}

Robust standards errors in parentheses; ${ }^{* *} p<0.01,{ }^{* *} p<0.05,{ }^{*} p<0.1$

This result is consistent with our expectations for two reasons: First, the income considered asis non-agricultural income and, therefore, generally less affected by climate change [91]. Second, many agricultural households can invest income from other activities to acquire agrarian inputs to boost production. One implication of this result is that diversification in economic activities reduces vulnerability to climate changes. These results are consistent with [92] findings, which showed that diversification of household activities reduced their exposure to climate shock by $7 \%$ in Northern Ghana.

Climate variables are not statistically significant but show a negative effect on vulnerability. This is also significant because the onset of droughts and floods leads to losses in production and income and exposes affected households to climate-related risk's adverse effects.

\subsection{Factors influencing households climate resilience}

We also estimated the marginal effect of different variables on households' perceived resilience to climate change. The results are presented in Table 5 and show that climate variables and income significantly influence households' perceived resilience to climatic events.

Climate variables such as the occurrence of floods and drought negatively affect household resilience. This implies that households who experienced floods or droughts are less resilient to climate change than others. The occurrence of floods and droughts weakens households' adaptive capacities and makes them less resilient. However, other works 
Fig. 6 Propensity score distributions (Remittances Full sample). Note: Panel in the left hand is a Kernel density plot that estimates the propensity score's underlying distribution before matching. The right-hand panel is a Kernel density plot that estimates the propensity score's underlying distributions after 1:1 matching. Control $=$ Households without cash transfers; Treated $=$ Households with cash transfers

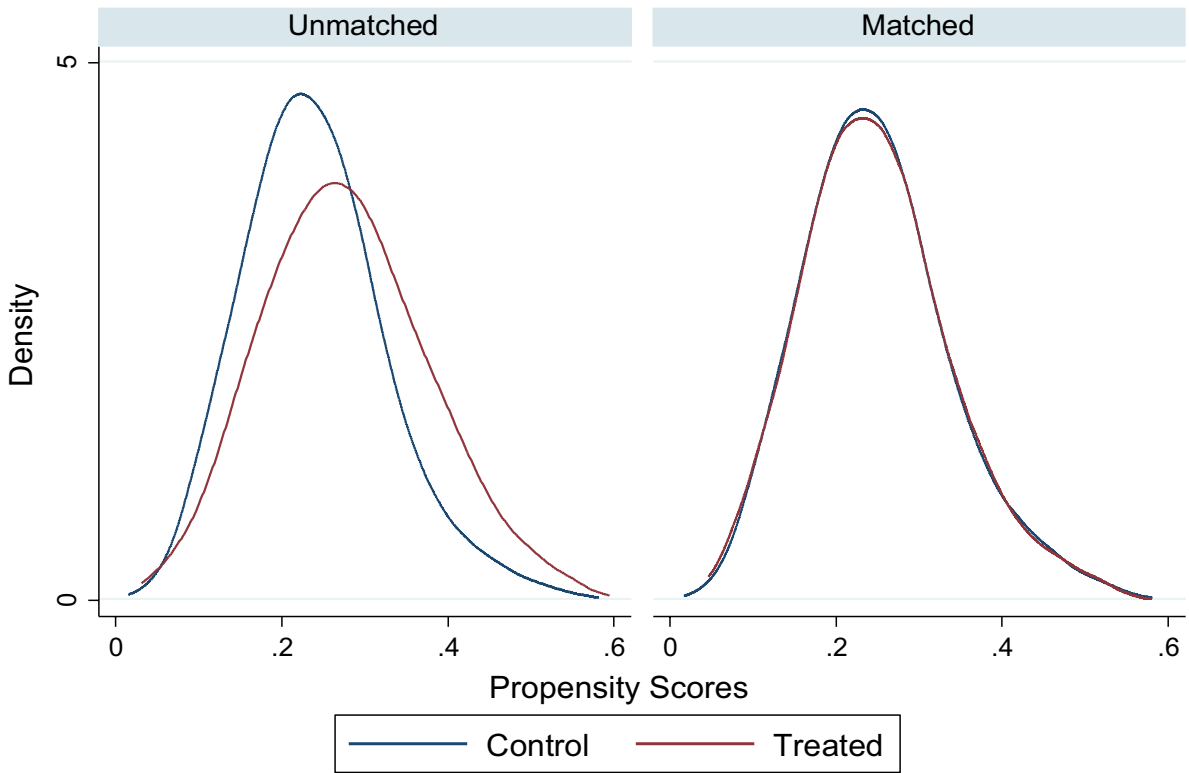

show that having once been a victim of floods or droughts increases knowledge of these hazards and boosts resilience capacity [93].

Although the different coefficients of the energy and water source variables are not statistically significant, the expected signs are obtained. This shows that potentially, the use of butane gas or electricity for cooking and water from the pump, borehole, or mineral water increases households' probability of being more resilient to climate shocks.

\subsection{Impacts of cash transfers: remittances}

This paper's other purpose is to account for the impact of remittances on household vulnerability and resilience to climate change. As our dataset allows us to distinguish remittance recipient households from non-recipient households, we use propensity score matching to deal with possible selection bias. As described in the methodology, we started by estimating propensity scores in checking for the balancing property.

\subsubsection{Propensity score distribution}

Figure 6 shows the kernel density plot plots of the estimated propensity scores for the entire treatment and the control groups. The plots show that the distribution of cash transfers recipient households is shifted to the right, indicating that these households have higher propensity score that non-recipient households. Thus, there's a high likelihood for households participating in the treatment group to receive remittances. We then balanced them because the two groups differ on the basic covariates.

The balancing technique revealed that the kernel distribution of recipients' propensity score and non-recipients households overlap almost entirely (Fig. 6). These plots provide the first proof that we successfully balanced the two groups on propensity scores.

We also check whether matching on each probability to receive the treatment balances of our regressors. Table 6 shows the standardized bias for the p-score before and after the matching, together with the achieved percentage of reduced bias, which on average is above $99 \%$ for each treatment considered.

\subsubsection{Covariates balance}

At this stage, we aim to achieve the balance for each basic covariate used in the computation of the propensity score when balancing groups. Figure 6 shows a dot plot comparing the standardized mean difference between $t$ and $c$ conditions in the full sample for the key covariates before and after matching based on propensity scores. Before matching, standardized differences are observable on the selected covariates in the sample. But after matching, the standardized 
Table 6 Balancing test for the propensity score Matchingkernel estimator

\begin{tabular}{|c|c|c|c|c|c|c|c|}
\hline $\begin{array}{l}\text { The score for } \\
\text { each treatment }\end{array}$ & Treated & Control & \%bias & \%reduct bias & t-test & $p>t$ & $\mathrm{R}=\mathrm{V}(\mathrm{T}) / \mathrm{V}(\mathrm{C})$ \\
\hline \multicolumn{8}{|l|}{ Recipient } \\
\hline Unmatched & 0.27569 & 0.23963 & 43.9 & 98.2 & 9.34 & 0.000 & $1.19^{*}$ \\
\hline Matched & 0.27569 & 0.27634 & -0.8 & & -0.13 & 0.898 & 0.98 \\
\hline \multicolumn{8}{|c|}{ External recipient } \\
\hline Unmatched & 0.03327 & 0.03252 & 4.3 & 99.9 & 0.88 & 0.379 & 0.92 \\
\hline Matched & 0.03327 & 0.03327 & -0.0 & & -0.00 & 0.999 & 1.13 \\
\hline \multicolumn{8}{|c|}{ Internal recipient } \\
\hline Unmatched & 0.24224 & 0.20697 & 43.4 & 99.0 & 9.25 & 0.000 & $1.20^{*}$ \\
\hline Matched & 0.24224 & 0.24187 & 0.5 & & 0.07 & 0.941 & 0.99 \\
\hline
\end{tabular}

Fig. 7 Dot plot showing the success of propensity scores matching for the means of covariates in the table. Note: The dark Squares represent the mean difference between the unmatched intervention and the control groups at baseline. The crosses represent the mean difference between recipients (treated) and non-recipients households (control) groups at baseline

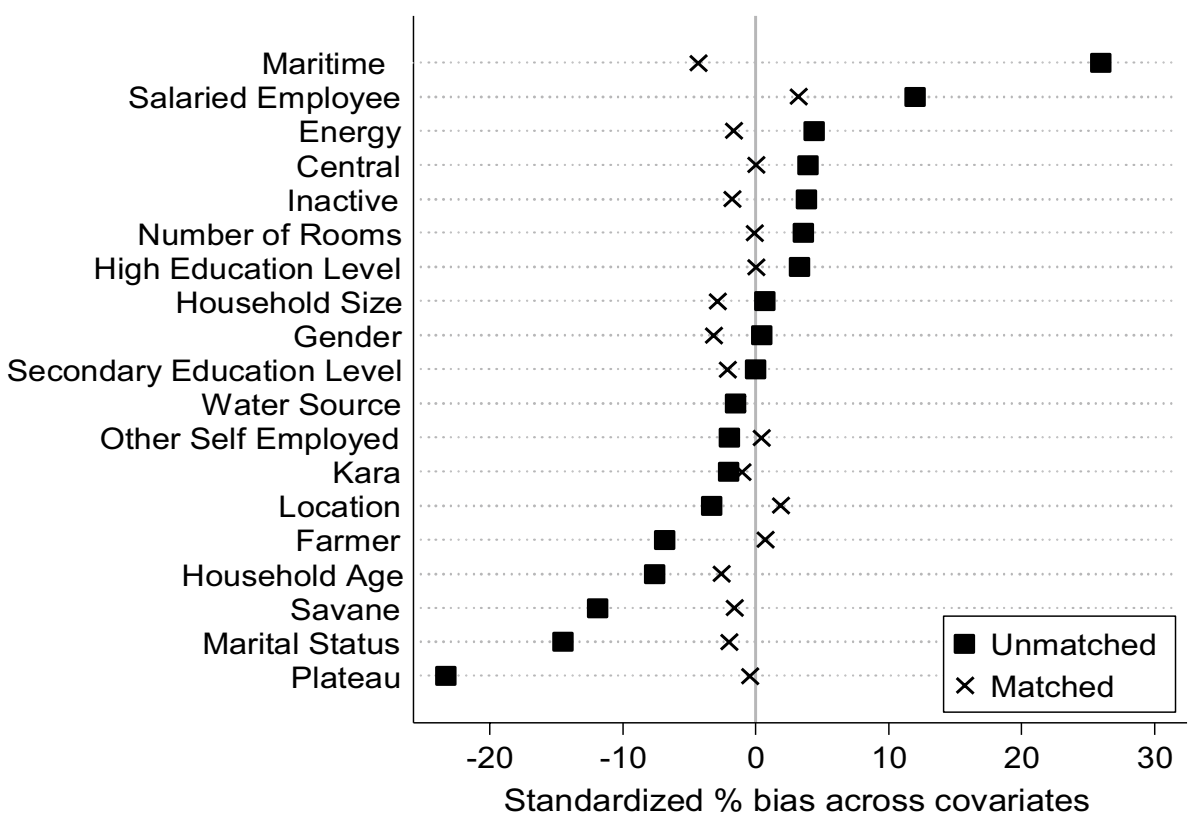

mean differences are close to zero, indicating that the treatment and the control groups balanced successfully on all covariates (Fig. 7).

\subsubsection{Determinants of cash transfers}

Table 7 below presents the logit regression of remittances on a wide range of individual characteristics and household information. The results reveal that remittance-receiving is positively associated with the number of rooms used by the households, the size of the households, and the region of residence but negatively affected by the age, the marital status, and the wealth status of the household heads. The dataset enables us to distinguish between external and internal remittances. The logit regression shows that the likelihood of external remittance-receiving is positively and significantly increased with the households' size because the effect is non-linear. However, the primary level of education and living in plateau regions like a plateau and central decrease the likelihood of receiving external remittance. Number of rooms in households and living in Lome increase the probability of receiving internal remittances. However, internal remittance tends to decrease with age, marital status of the household head, farmer, and rich.

\subsubsection{Cash transfers impact on climate change impact, vulnerability, and resilience}

Table 8 shows the estimated ATT on a tree set of climate variables: climate impact perception, vulnerability, and households' resilience. The findings reveal that cash transfers did not significantly impact the household's perception of climate 
Table 7 Determinants of remittances

\begin{tabular}{|c|c|c|c|}
\hline Variables & $\begin{array}{l}\text { (1) } \\
\text { Recipients }\end{array}$ & $\begin{array}{l}(2) \\
\text { Recipients: external } \\
\text { remittances }\end{array}$ & $\begin{array}{l}\text { (3) } \\
\text { Recipients: } \\
\text { internal remit- } \\
\text { tances }\end{array}$ \\
\hline Household head age & $\begin{array}{l}-0.00902^{* *} \\
(0.00370)\end{array}$ & $\begin{array}{l}0.00426 \\
(0.00832)\end{array}$ & $\begin{array}{l}-0.0109^{* * * *} \\
(0.00394)\end{array}$ \\
\hline Household size & $\begin{array}{l}0.00860 * \\
(0.0415)\end{array}$ & $\begin{array}{l}0.190^{*} \\
(0.109)\end{array}$ & $\begin{array}{l}-0.0202 \\
(0.0436)\end{array}$ \\
\hline Size square & $\begin{array}{l}-0.000598 \\
(0.00264)\end{array}$ & $\begin{array}{l}-0.0117^{*} \\
(0.00710)\end{array}$ & $\begin{array}{l}0.00103 \\
(0.00278)\end{array}$ \\
\hline Number of rooms & $\begin{array}{l}0.0684^{* *} \\
(0.0311)\end{array}$ & $\begin{array}{l}0.00836 \\
(0.0744)\end{array}$ & $\begin{array}{l}0.0756^{* * *} \\
(0.0326)\end{array}$ \\
\hline Gender $($ Woman $=1)$ & $\begin{array}{l}0.0301 \\
(0.116)\end{array}$ & $\begin{array}{l}0.110 \\
(0.282)\end{array}$ & $\begin{array}{l}0.00886 \\
(0.122)\end{array}$ \\
\hline Location (Urban $=1$ ) & $\begin{array}{l}-0.143 \\
(0.126)\end{array}$ & $\begin{array}{l}-0.174 \\
(0.310)\end{array}$ & $\begin{array}{l}-0.128 \\
(0.133)\end{array}$ \\
\hline Marital status (Polygamous $=1$ ) & $\begin{array}{l}-0.478^{* * * *} \\
(0.153)\end{array}$ & $\begin{array}{l}-0.0354 \\
(0.348)\end{array}$ & $\begin{array}{l}-0.535^{* * *} \\
(0.165)\end{array}$ \\
\hline Education (Primary $=1$ ) & $\begin{array}{l}-0.0468 \\
(0.114)\end{array}$ & $\begin{array}{l}-0.862^{* *} \\
(0.348)\end{array}$ & $\begin{array}{l}0.0829 \\
(0.118)\end{array}$ \\
\hline Salaried employee & $\begin{array}{l}0.117 \\
(0.134)\end{array}$ & $\begin{array}{l}0.489 \\
(0.324)\end{array}$ & $\begin{array}{l}0.0420 \\
(0.141)\end{array}$ \\
\hline Farmer & $\begin{array}{l}-0.330 \\
(0.220)\end{array}$ & $\begin{array}{l}0.216 \\
(0.498)\end{array}$ & $\begin{array}{l}-0.405^{*} \\
(0.235)\end{array}$ \\
\hline Inactive & $\begin{array}{l}0.195 \\
(0.186)\end{array}$ & $\begin{array}{l}0.288 \\
(0.458)\end{array}$ & $\begin{array}{l}0.161 \\
(0.195)\end{array}$ \\
\hline Other self-employed & $\begin{array}{l}-0.119 \\
(0.138)\end{array}$ & $\begin{array}{l}0.523 \\
(0.326)\end{array}$ & $\begin{array}{l}-0.228 \\
(0.145)\end{array}$ \\
\hline Rich & $\begin{array}{l}-0.286^{* * *} \\
(0.108)\end{array}$ & $\begin{array}{l}-0.330 \\
(0.258)\end{array}$ & $\begin{array}{l}-0.254^{* *} \\
(0.114)\end{array}$ \\
\hline Lome & $\begin{array}{l}0.589^{* * *} \\
(0.198)\end{array}$ & $\begin{array}{l}-0.581 \\
(0.401)\end{array}$ & $\begin{array}{l}0.868^{* * *} \\
(0.223)\end{array}$ \\
\hline Maritime & $\begin{array}{l}1.170^{* * *} \\
(0.206)\end{array}$ & $\begin{array}{l}-0.425 \\
(0.405)\end{array}$ & $\begin{array}{l}1.461^{* * *} \\
(0.230)\end{array}$ \\
\hline Plateau & $\begin{array}{l}-0.0800 \\
(0.213)\end{array}$ & $\begin{array}{l}-1.046^{* *} \\
(0.473)\end{array}$ & $\begin{array}{l}0.203 \\
(0.237)\end{array}$ \\
\hline Central & $\begin{array}{l}0.529 * * \\
(0.214)\end{array}$ & $\begin{array}{l}-1.450^{* *} \\
(0.566)\end{array}$ & $\begin{array}{l}0.915^{* * *} \\
(0.236)\end{array}$ \\
\hline Kara & $\begin{array}{l}0.449^{* *} \\
(0.211)\end{array}$ & $\begin{array}{l}-0.337 \\
(0.397)\end{array}$ & $\begin{array}{l}0.653^{* * * *} \\
(0.237)\end{array}$ \\
\hline Constant & $\begin{array}{l}-1.061^{* * *} \\
(0.274)\end{array}$ & $\begin{array}{l}-3.491^{* * *} \\
(0.576)\end{array}$ & $\begin{array}{l}-1.357^{* * *} \\
(0.299)\end{array}$ \\
\hline Observations & 2313 & 2313 & 2,313 \\
\hline
\end{tabular}

Robust standard errors in parentheses; ${ }^{* * *} p<0.01,{ }^{* *} p<0.05,{ }^{*} p<0.1$

impact, exposure, and resilience for tree sets of matching methods (Nearest-neighbor, radius, and Kernel). However, the stratification method shows that cash transfers positively impact households' climate impact perception. The level of climate impact perception is $7.3 \%$ higher in remittance-receiving households than non-recipients households. This is consistent with our expectations because remittances are obtained from families, household members, or friends and can be invested, for example, in the procurement of farm inputs to boost their production. Because farm activities are more affected by climatic conditions, remittances households can lose more output due to climate change than nonrecipient households. 
Table 8 Impact of cash transfers on climate risk, vulnerability, and resilience

\begin{tabular}{llll}
\hline Recipient & Climate risks & Vulnerability & Resilience \\
\hline Nearest neighbor & 0.038 & 0.022 & 0.026 \\
& $(0.068)$ & $(0.017)$ & $(0.024)$ \\
Stratification & $0.073^{* * *}$ & 0.017 & 0.011 \\
& $(0.034)$ & $(0.013)$ & $(0.018)$ \\
Radius (0.01) & - & 0.010 & 0.002 \\
& & $(0.013)$ & $(0.018)$ \\
Kernel & 0.069 & 0.014 & 0.008 \\
External & $(0.056)$ & $(0.013)$ & $(0.018)$ \\
Nearest neighbor & & & \\
& -0.073 & -0.039 & 0.026 \\
Stratification & $(0.170)$ & $(0.049)$ & $(0.060)$ \\
& 0.125 & 0.013 & 0.008 \\
Radius (0.01) & $(0.086)$ & $(0.032)$ & $(0.044)$ \\
Kernel & - & 0.013 & 0.007 \\
& & $(0.032)$ & $(0.044)$ \\
Internal & 0.125 & 0.013 & 0.008 \\
Nearest neighbor & $(0.160)$ & $(0.033)$ & $(0.045)$ \\
Stratification & & & \\
Radius (0.01) & 0.094 & $0.029^{*}$ & 0.007 \\
Kernel & $(0.067)$ & $(0.018)$ & $(0.027)$ \\
& 0.046 & 0.013 & 0.006 \\
& $(0.036)$ & $(0.014)$ & $(0.019)$ \\
& - & 0.013 & 0.003 \\
& & $(0.014)$ & $(0.019)$ \\
& 0.056 & 0.014 & 0.006 \\
& $(0.059)$ & $(0.014)$ & $(0.018)$ \\
\hline
\end{tabular}

The impact of remittance on vulnerability and resilience shows the expected sign for almost all the matching methods but are not statistically significant except for internal remittances. Remittances from Togo are positively associated with household vulnerability perception. This means that the probability of becoming less vulnerable to climate change increases as a household receives remittance. This is also consistent with our expectations. On average, internal remittances increase the household's capacity to be less vulnerable to climate change by $2.9 \%$ than non-recipient households. One implication of these results is that; Togolese households can remain on social networks (families, friends) in Togo as a coping mechanism for climate-related shocks. Internal remittances behave here as social assurance for recipients' households in the moment of shocks. Finally, there's no statistically significant impact of remittances on household's resilience to climate change. However, the expected sign is obtained. This means that remittances can play a role in building households' resilience to climate change.

The Nearest Neighbor Matching technique involves matching each treatment unit to the comparison unit with the closest propensity score. Matching can be done with and without replacement. The Stratification or interval matching partitions the joint support into different strata (or gaps) and calculates the program's impact within each interval. The program effect is, therefore, the mean difference in outcomes between treated and control observations. The Radius Matching involves matching with replacement, only among propensity scores within a specific range. It implies imposing a threshold or « tolerance» on the maximum propensity score distance. The Kernel Matching is a non-parametric matching estimator that uses all nonparticipants' weighted average to construct each participant's counterfactual match. Kernel matching is analogous to regression on the constant term.

\subsubsection{Robustness Cheick of ATT}

One approach to check our findings' robustness is to estimate the propensity score equation and then use the different matching methods to compare the results. We also check the robustness by applying direct nearest-neighbor matching instead of estimating the propensity score equation first. The idea is, if both methods give similar results, then the findings are assumed to be more reliable. According to our results presented in Table 9, they are consistent with earlier findings. 


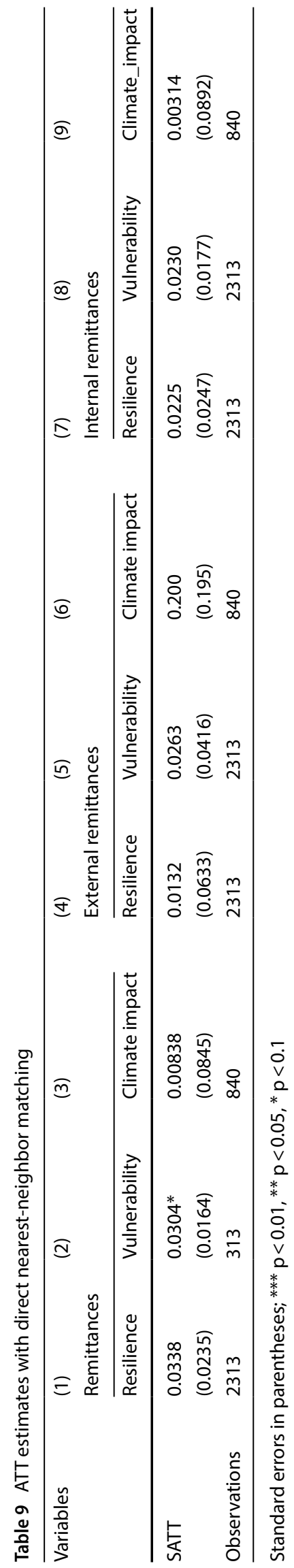


Table 10 Mantel-Haenszel bounds for variable

\begin{tabular}{llcll}
\hline Gamma & Q_mh+ & Q_mh- & p_mh+ & p_mh- \\
\hline 1 & 1.52 & 1.52 & 0.06 & 0.06 \\
2 & 1.16 & 4.60 & 0.12 & 0.00 \\
3 & 2.90 & 6.60 & 0.00 & 0.00 \\
4 & 4.20 & 8.16 & 0.00 & 0.00 \\
5 & 5.25 & 9.47 & 0.00 & 0.00 \\
6 & 6.16 & 10.62 & 0.00 & 0.00 \\
7 & 6.97 & 11.66 & 0.00 & 0.00 \\
8 & 7.70 & 12.61 & 0.00 & 0.00 \\
\hline
\end{tabular}

Gamma: odds of differential assignment due to unobserved factors

Q_mh+: Mantel-Haenszel statistic (assumption: overestimation of treatment effect)

Q_mh-: Mantel-Haenszel statistic (assumption: underestimation of treatment effect)

p_mh+: significance level (assumption: overestimation of treatment effect)

p_mh-: significance level (assumption: underestimation of treatment effect)

Table 11 Instruments analysis

\begin{tabular}{lllll}
\hline Instruments & $(1)$ & $(2)$ & $(3)$ & $(4)$ \\
& Climate & Vulnerability & Resilience & Remittances \\
\hline Unemployment & -0.0549 & -0.0266 & -0.0251 & $0.112^{* * *}$ \\
& $(0.310)$ & $(0.250)$ & $(0.250)$ & $(0.173)$ \\
Older persons & -0.00975 & 0.0867 & -0.0560 & $-0.174^{* *}$ \\
Constant & $(0.112)$ & $(0.106)$ & $(0.111)$ & $(0.0840)$ \\
Observations & $-0.168^{* * *}$ & $-1.511^{* * *}$ & $1.562^{* * *}$ & $-0.778^{* * *}$ \\
\hline
\end{tabular}

\subsubsection{Sensitivity analysis: Mantel-Haenszel statistic}

We look at Q_mh + and Q_mh- obtained from STATA ${ }^{4}$ output and reported them in Table 10 below. The upper bounds of significance levels of gamma $=1.0$ are 0.06 . All the gammas are significant at $1 \%$ from 3 . It will also be pointed out that the level of significance of the borders decreases initially and increases considerably. We also observe similar trends, considering the other outcomes. Hence, we can conclude that our results are not very sensitive to any bias that would increase households' probabilities of receiving cash transfers.

\subsubsection{Instrumental variable results}

As said in the method section, we test whether the instruments are not correlated with the outcome variables, a condition for valid instruments. Table 11 below shows that the instruments are accurate, with high explanatory power when used together.

The results clearly show that the instruments are good explanatory variables for the endogenous migrant remittances variable as they are all statistically significant at $1 \%$. Moreover, as expected, the instruments have no statistically significant effect on the outcome variables, climate impacts, vulnerability, and resilience. This justifies the validity of our instruments.

Analysis of the results of the instrumental variable estimates (Table 12) shows that the effect of migrant remittances on climate impacts, vulnerability, and resilience of households to climate threats was underestimated in previous regressions. After dealing with endogeneity, we see a statistically positive effect of remittance on building on household capacity to be less impacted by climate change, less vulnerable, and more resilient to climate-related risk.

\footnotetext{
4 STATA is a statistical software used to obtain the results.
} 
Table 12 Instrumental variable probit estimates (all instruments: marginal effects)

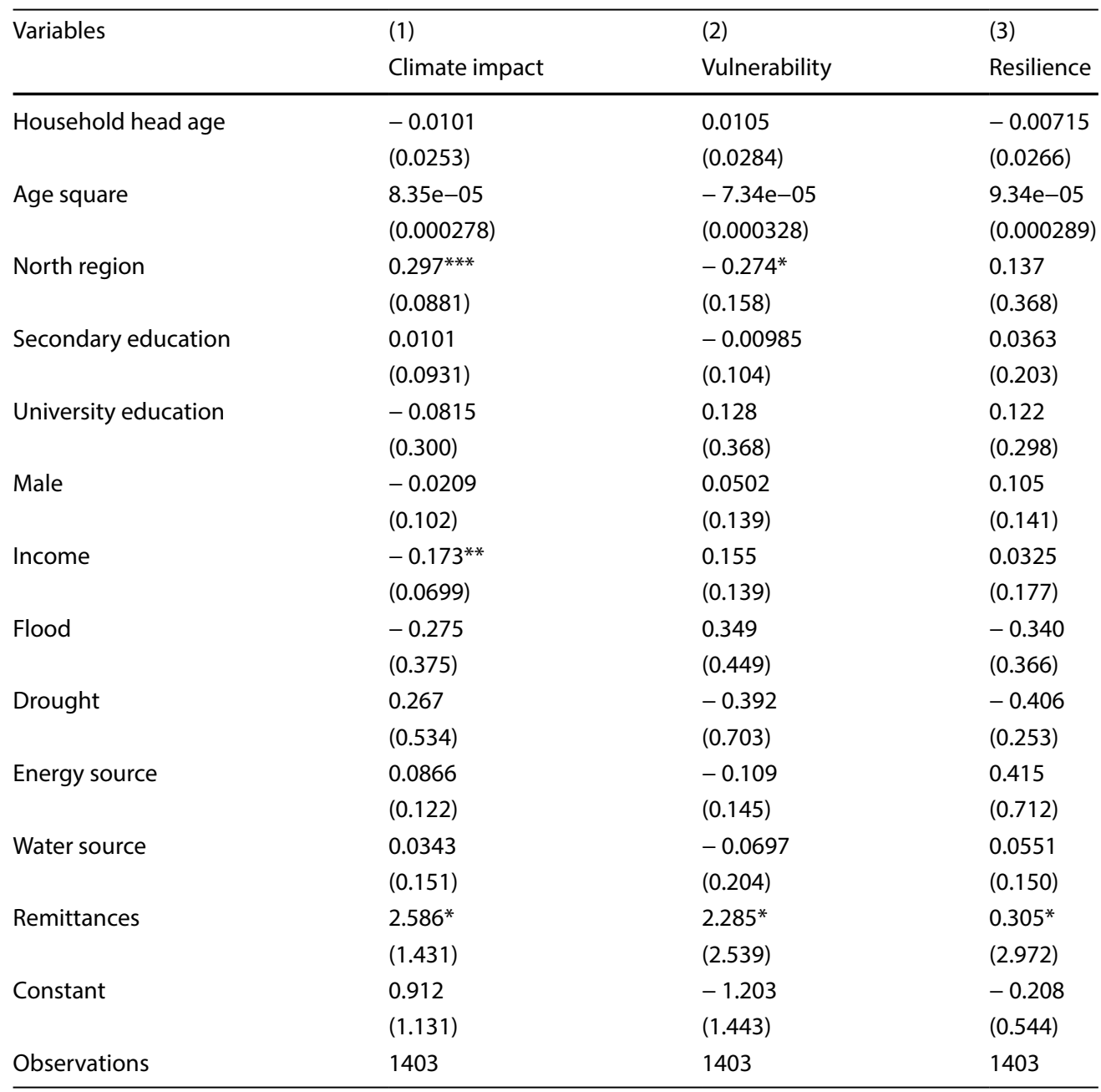

Standard errors in parenthesis; ${ }^{* *} p<0.01,{ }^{* *} p<0.05,{ }^{*} p<0.1$

\section{Concluding remarks}

This paper analyses the effect of climate-related risk on households in Togo in a holistic way. Unlike other studies, this study combines impacts, vulnerability, and resilience in a subjective approach.

The results show that age of the head of household, gender, per capita household expenditure, energy and water sources, and migrant remittances are significantly correlated with the perceived impacts of climate-related impacts on household living standards in Togo. The revealed climate-related vulnerability of households is influenced considerably by household income, drought, floods, and Togo remittances. Finally, Togolese households' climate resilience is mainly determined by the household's income and remittances. This study is highly relevant because it clarifies how socioeconomic and other factors influence the three aspects of climate analyzed. This disaggregated way of climate analysis is more specific for climate actions.

The results also show absolute heterogeneity in factors determining different aspects of climate-related risk and extreme events. Some factors significantly affect one aspect of climate-related impacts but do not significantly affect the other two aspects and vice versa. Moreover, the direction of the effect itself differs according to the aspect of climate change considered. Therefore, a broader strategy is needed to address climate-related risk consequences rather than specific factors [91]. However, considering the overall role of migrant remittances on households, it can be deduced that these funds relieve the additional income constraints imposed by climate shocks by facilitating investments and maintaining a decent living standard. It is important that cash transfers and support programs for activities that create and increase household income already undertaken by the Togolese government be strengthened and extended to all 
the most underprivileged populations to boost their ability to survive and be less vulnerable to the threats of climate threats and their resilience.

Acknowledgements Not applicable.

Authors' contributions KS and VN analyzed and interpreted the economic data. KS performed the economic analysis and was a major contributor in writing the manuscript. All authors read and approved the final manuscript.

Funding All sources of funding for the research reported should be declared.

Availability of data and materials Data for this article are available.

Ethics approval and consent to participate Not applicable.

Consent for publication Not applicable.

Competing interests We declare that they have no competing interests.

Open Access This article is licensed under a Creative Commons Attribution 4.0 International License, which permits use, sharing, adaptation, distribution and reproduction in any medium or format, as long as you give appropriate credit to the original author(s) and the source, provide a link to the Creative Commons licence, and indicate if changes were made. The images or other third party material in this article are included in the article's Creative Commons licence, unless indicated otherwise in a credit line to the material. If material is not included in the article's Creative Commons licence and your intended use is not permitted by statutory regulation or exceeds the permitted use, you will need to obtain permission directly from the copyright holder. To view a copy of this licence, visit http://creativecommons.org/licenses/by/4.0/.

\section{References}

1. McCarthy JJ, Canziani OF, Leary NA, Dokken DJ, White KS. Climate change 2001: impacts, adaptation, and vulnerability: contribution of Working Group II to the third assessment report of the Intergovernmental Panel on Climate Change, vol. 2. Cambridge: Cambridge University Press; 2001.

2. Mpambela M, Mabvurira V. Effects of climate change and their indelible impact on social work profession in Zimbabwe. Afr J Soc Work. 2017;7(2):30-5.

3. Chhogyel N, Kumar L. Climate change and potential impacts on agriculture in Bhutan: a discussion of pertinent issues. Agric Food Secur. 2018;7:79.

4. Aryal JP, Sapkota TB, Khurana R, Khatri-Chhetri A, Jat ML. Climate change and agriculture in South Asia: adaptation options in smallholder production systems. Environ Dev Sust. 2019;1:31.

5. Briguglio L. Small island developing states and their economic vulnerabilities. World Dev. 1995;23(9):1615-32.

6. Bettencourt S, et al. Not if but when: Adapting to natural hazards in the Pacific Islands region-a policy note. New York: The World Bank; 2006.

7. Kelman I, Lewis J. Ecology and vulnerability: islands and sustainable risk management. Insula-Paris. 2005;14(2):5.

8. Lewis J. An island characteristic. SHIMA. 2009;3(1):3-15.

9. Islam R, Kamaruddin R, Ahmad SA, Jan SJ, Anuar AR. A review on mechanism of flood disaster management in Asiaf. Int Rev Manag Market. 2016;6:1.

10. Dano UL, et al. Flood susceptibility mapping using GIS-based analytic network process: A case study of Perlis Malaysia. Water. 2019;11(3):615.

11. Adger WN, Kelly M, Winkels A, Huy LQ, Locke C. Migration, remittances, livelihood trajectories, and social resilience. AMBIO. 2002;31(4):358-66.

12. Fadina AMR, Barjolle D. Farmers' adaptation strategies to climate change and their implications in the Zou department of South Benin. Environments. 2018;5(1):15.

13. Tarfa PY, Ayuba HK, Onyeneke RU, Idris N, Nwajiuba CA, Igberi CO. Climate change perception and adaptation in Nigeria's Guinea Savanna: Empirical evidence from farmers in Nasarawa State Nigeria. Appl Ecol Environ Res. 2019;17:7085-112.

14. Onyeneke RU. Does climate change adaptation lead to increased productivity of rice production? Lessons from Ebonyi State Nigeria. Renew Agric Food Syst. 2019;1:15.

15. Orozco M. Understanding the remittance economy in Haiti. Washington: World Bank; 2006.

16. P. Deshingkar, M. M, Aheeyar M. Remittances in crisis: Sri Lanka after the tsunami. Humanitarian Policy Group Background Paper. 2006.

17. Mohapatra S, Joseph G, Ratha D. Remittances and natural disasters: ex-post response and contribution to ex-ante preparedness. New York: The World Bank; 2009.

18. Yang D, Choi H. Are remittances insurance? Evidence from rainfall shocks in the Philippines. World Bank Econ Rev. 2007;21(2):219-48.

19. Ratha D, Sirkeci I. Remittances and the global financial crisis. Migr Lett. 2010;7(2):125-31.

20. N. Prakash, The development impact of workers' remittances in Fiji.' Unpublished Masters Thesis Massey University, Palmerston North New Zealand. 2009.

21. Le Dé L, Rey T, Leone F, Gilbert D. Sustainable livelihoods and effectiveness of disaster responses: a case study of tropical cyclone Pam in Vanuatu. Nat Hazards. 2018;91(3):1203-21. 
22. Wentworth C. Unhealthy aid: food security programming and disaster responses to Cyclone Pam in Vanuatu. Anthropol Forum. 2020;30(1-2):73-90.

23. Stark O, Levhari D. On migration and risk in LDCs. Econ Dev Cult Change. 1982;31(1):191-6.

24. Boccagni P. Addressing transnational needs through migration? An inquiry into the reach and consequences of migrants' social protection across borders. Global Social Policy. 2017;17(2):168-87.

25. Saksela-Bergholm S. Welfare beyond Borders: Filipino Transnational Families'Informal Social Protection Strategies. Social inclusion. 2019.

26. Kapur D. Remittances: The New Development Mantra? G-24 Discussion Papers 29. 2004.

27. Le Dé L, Gaillard JC, Friesen W, Pupualii M, Brown C, Aupito A. Our family comes first: Migrants' perspectives on remittances in disaster. Migr Dev. 2016;5(1):130-48.

28. P. Giuliano, M. Ruiz-Arranz, Remittances, financial development and growth IMF Working paper 05/234. International Monetary Fund, Washington DC, USA. 2005.

29. Fayissa B, Nsiah C. The impact of remittances on economic growth and development of Africa. Department of Economics and Finance Working Paper Series, February 2008. 2008.

30. Fromentin V. The long-run and short-run impacts of remittances on financial development in developing countries. Q Rev Econ Finance. 2017;66:192-201.

31. Akcay S. Remittances and financial development in Bangladesh: substitutes or complements? Appl Econ Lett. 2020;27(14):1206-14.

32. World Bank, Rapport 2018 sur la pauvreté, la prospérité partagée : compléter le puzzle de la pauvreté. World Bank. 2018. https://www. banquemondiale.org/fr/research/brief/poverty-and-shared-prosperity-2018-piecing-together-the-poverty-puzzle-frequently-asked-quest ions. Accessed 17 Jul 2020.

33. S. Abi, The Togolese migrants - largest donors in Togo. CADTM. 2020. http://www.cadtm.org/The-Togolese-migrants-largest. Accessed 22 Oct 2020.

34. Karim A. The household response to persistent natural disasters: Evidence from Bangladesh. World Dev. 2018;103:40-59.

35. Su Y, Lim L. A tide that does not lift all boats: the surge of remittances in post-disaster recovery in Tacloban City Philippines. Crit Asian Stud. 2018;50(1):67-85.

36. Walsh B, Hallegatte S. Measuring Natural Risks in the Philippines: Socio-economic Resilience and Wellbeing Losses. Econ Disast Clim Change. 2020;1:45

37. Le De L, Gaillard JC, Friesen W. Remittances and disaster: a review. Int J Disast Risk Reduct. 2013;4:34-43.

38. Banerjee $\mathrm{S}$, et al. Do financial remittancces build household-level adaptive capacity? A case study of flood-affected households in India. 2017.

39. Tacoli C. Not only climate change: mobility, vulnerability and socio-economic transformations in environmentally fragile areas in Bolivia. IIED: Senegal and Tanzania; 2011.

40. Dumenu WK, Obeng EA. Climate change and rural communities in Ghana: social vulnerability, impacts, adaptations and policy implications. Environ Sci Policy. 2016;55:208-17.

41. Wossen T, Berger T, Swamikannu N, Ramilan T. Climate variability, consumption risk and poverty in semi-arid Northern Ghana: Adaptation options for poor farm households. Environ Dev. 2014;12:2-15.

42. Jones L, Tanner T.'Subjective resilience': using perceptions to quantify household resilience to climate extremes and disasters. Reg Environ Change. 2017;17(1):229-43.

43. Haque C, Etkin D. People and community as constituent parts of hazards: the significance of societal dimensions in hazards analysis. Nat Hazards. 2007:41(2):271-82.

44. Shaw R, Sharma A, Takeuchi Y. Indigenous knowledge and disaster risk reduction: From practice to policy. New York: Nova Science Publishers Inc; 2009.

45. Wisner B, Blaikie M, Blaikie T, Cannon ID. At risk: natural hazards, people's vulnerability and disasters. Abingdon: Psychology Press; 2004.

46. Gaillard J-C, Maceda EA, Stasiak E, Le Berre I, Espaldon MVO. Sustainable livelihoods and people's vulnerability in the face of coastal hazards. J Coast Conserv. 2009;13(2-3):119.

47. Gaillard JC. From marginality to further marginalization: experiences from the victims of the July 2000 Payatas trashslide in the Philippines. J Disast Risk Stud. 2009;2(3):197-215.

48. Cinner JE, et al. Building adaptive capacity to climate change in tropical coastal communities. Nat Climate Change. 2018;8(2):117-23.

49. Wu T. The role of remittances of crises. Humanitarian Policy Group background paper. 2009.

50. Lindley A. Protracted displacement and remittances: the view from Eastleigh, Nairobi. 2007.

51. Generoso R. How do rainfall variability, food security and remittances interact? The case of rural Mali. Ecol Econ. 2015;114:188-98.

52. A. Heijmans, "Vulnerability": A Matter of Perception. 2001.

53. T. Hilhorst, Mapping vulnerability: disasters, development, and people. Routledge, 2004.

54. Pairama J, Le Dé L. Remittances for disaster risk management: perspectives from Pacific Island migrants living in New Zealand. Int J Disast Risk Sci. 2018;9(3):331-43.

55. Scoones I. Livelihoods perspectives and rural development. The journal of peasant studies. 2009;36(1):171-96.

56. Bakkensen LA, Fox-Lent C, Read LK, Linkov I. Validating resilience and vulnerability indices in the context of natural disasters. Risk Anal. 2017;37(5):982-1004.

57. Cutter SL, Ash KD, Emrich CT. Urban-rural differences in disaster resilience. Ann Am Assoc Geogr. 2016;106(6):1236-52.

58. Zemba V, et al. Defining, measuring, and enhancing resilience for small groups. Safety Sci. 2019;120:603-16.

59. Comfort L, et al. Reframing disaster policy: the global evolution of vulnerable communities. Global Environ Change Part B. 1999;1(1):39-44.

60. Baro M, Deubel TF. Persistent hunger: perspectives on vulnerability, famine, and food security in sub-Saharan Africa. Annu Rev Anthropol. 2006;35:521-38.

61. Renaud FG, Bogardi JJ, Dun O, Warner K. Control, adapt or flee: How to face environmental migration? UNU-EHS. 2007.

62. Stern N, Stern NH. The economics of climate change: the Stern review. Cambridge: Cambridge University Press; 2007.

63. Musah-Surugu IJ, Ahenkan A, Bawole JN, Darkwah SA. Migrants' remittances: A complementary source of financing adaptation to climate change at the local level in Ghana. Int J Climate Change Strat Manag. 2018;10(1):178-96. 
64. Azam M, Haseeb M, Samsudin S. The impact of foreign remittances on poverty alleviation : global evidence. Econ Sociol. 2016;9:264-81.

65. Musakwa MT, Odhiambo NM. Remittance inflows and poverty Nexus in Botswana: a multivariate approach. J Sust Finan Invest. 2020;1:15.

66. Suleri AQ, Savage K. Remittances in crises: a case study from Pakistan. London: Sustainable Development Policy Institute London; 2006.

67. Ellis F. Household strategies and rural livelihood diversification. J Dev Stud. 1998;35(1):1-38.

68. Ponce J, Olivié Aldasoro L, Onofa M. Remittances for development: a case study of the impact of remittances on human development in Ecuador. Elcano Newslett. 2008;48:33.

69. Wooldridge JM. Introduction to econometrics: Europe. Middle East and Africa Edition: Cengage Learning; 2014.

70. Greene WH. Econometric analysis. 2nd ed. Englewood Cliffs, NJ: Pretence Hall; 1993.

71. Clément M. Remittances and household expenditure patterns in Tajikistan: A propensity score matching analysis. Asian Dev Rev. 2011;28:2.

72. Esquivel G, Huerta-Pineda A. Remittances and poverty in Mexico: a propensity score matching approach. Integr Trade J. $2007 ; 27(11): 45-57$.

73. Bertoli S, Marchetta F. Migration, remittances and poverty in Ecuador. J Dev Stud. 2014;50(8):1067-89.

74. Rubin DB. The use of matched sampling and regression adjustment to remove bias in observational studies. Biometrics. 1973;21:185-203.

75. Ghalib TK, Al-Hattami AA. Holistic versus analytic evaluation of EFL writing: a case study. English Lang Teach. 2015;8(7):225-36.

76. Mora-Rivera J, Cerón-Monroy H, García-Mora F. The impact of remittances on domestic tourism in Mexico. Ann Tour Res. 2019;76:36-52.

77. Abadie A, Imbens GW. Bias-corrected matching estimators for average treatment effects. J Bus Econ Stat. 2011;29(1):1-11.

78. Ghalib AK, Malki I, Imai KS. The impact of microfinance and its role in easing poverty of rural households: estimations from Pakistan. Kobe University. 2011;9(1):1-37.

79. Rosenbaum PR, Rubin DB. The central role of the propensity score in observational studies for causal effects. Biometrika. 1983;70(1):41-55.

80. Becker SO, Ichino A. Estimation of average treatment effects based on propensity scores. Stata J. 2002;2(4):358-77.

81. Cameron AC, Trivedi K. Microeconometrics using Stata (revised ed.). Number musr in Stata Press books. StataCorp LP, 2010.

82. Nannicini T. Simulation-based sensitivity analysis for matching estimators. The stata journal. 2007;7(3):334-50.

83. Becker SO, Caliendo M. Sensitivity analysis for average treatment effects. Stata J. 2007;7(1):71-83.

84. Matano A, Ramos R. Remittances and educational outcomes: evidence for Moldova. SEARCH working paper WP3/10. April 2013. http:// www.ub.edu/searchproject. 2013.

85. Cox D, Jimenez E. Coping with apartheid: inter-household transfers over the life-cycle in South Africa. Boston College and World Bank, draft, 1997.

86. Mansour W, Chaaban J, Litchfield J. The impact of migrant remittances on school attendance and education attainment: evidence from Jordan. Int Migr Rev. 2011;45(4):812-51.

87. Matano A, Ramos R. Remittances and educational outcomes: evidence for Moldova. SEARCH working paper WP3/10. April 2013. http:// www.ub.edu/searchproject. 2013.

88. UNDP, Impact des changements Climatiques: Analyse des volets relatifs à la pauvreté au Togo. Rapport final. 2011. 2011. https://psycn et.apa.org/record/1973-31269-000. Accessed 22 Oct 2020.

89. QUIBB, Questionnaire unifié des indicateurs de base du bien-être 2015. 2015.

90. Ncube M, et al. Climate change, household vulnerability and smart agriculture: the case of two South African provinces. J Disast Risk Stud. 2016;8(2):14

91. Adzawla W, Azumah SB, Anani Y, Donkoh SA. Analysis of farm households' perceived climate change impacts, vulnerability and resilience in Ghana. Sci Afr. 2020;8:e00397.

92. Adzawla W, Baumüller H. Effects of livelihood diversification on gendered climate vulnerability in Northern Ghana. Environ Dev Sustain. 2020;2:56

93. Asmamaw M, Mereta ST, Ambelu A. Exploring households' resilience to climate change-induced shocks using Climate Resilience Index in Dinki watershed, central highlands of Ethiopia. PLoS ONE. 2019;14(7):e0219393.

Publisher's Note Springer Nature remains neutral with regard to jurisdictional claims in published maps and institutional affiliations. 